\title{
Biology of Leaf Miner, Liriomyza trifolii (Burgess) on Tomato and the Effect of Different Temperature Regimes on its Developmental Period
}

\author{
N. Kasar* and S. Jha \\ Department of Agricultural Entomology, Faculty of Agriculture, Bidhan Chandra Krishi \\ Viswavidyalaya, Mohanpur, Nadia, West Bengal-741252, India \\ *Corresponding author
}

Keywords

Leafminer, Tomato,

Biology,

temperature

Article Info

Accepted:

20 January 2021

Available Online:

10 February 2021

\section{A B S T R A C T}

Studies on biology of leaf miner, Liriomyza trifolii were carried out on tomato plant in the Plant Protection Laboratory of Department of Agricultural Entomology, Bidhan Chandra Krishi Viswavidyalaya, Mohanpur, Nadia, West Bengal. The egg, first instar larva, second instar larva, third instar larva and pupa measured about $0.21 \pm 0.03 \mathrm{~mm} \times 0.11 \pm 0.02 \mathrm{~mm}, 0.54 \pm 0.07 \mathrm{~mm} \times 0.33 \pm 0.07$ $\mathrm{mm}, 1.41 \pm 0.06 \mathrm{~mm} \times 0.5 \pm 0.04 \mathrm{~mm}, 2.09 \pm 0.02 \mathrm{~mm} \times 1.19 \pm 0.04 \mathrm{~mm}$ and 1.78 $\pm 0.09 \mathrm{~mm} \times 0.68 \pm 0.06 \mathrm{~mm}$ in length and breadth, respectively. The length of body and wing expanse in adult male and female were found to be in a range of $1.46 \pm 0.08 \mathrm{~mm}$ and $1.22 \pm 0.06 \mathrm{~mm}, 1.68 \pm 0.09 \mathrm{~mm}$ and $1.35 \pm 0.07 \mathrm{~mm}$, respectively. The biological studies of $L$. trifolii under different temperature regimes of $15^{\circ} \mathrm{C}, 20^{\circ} \mathrm{C}, 25^{\circ} \mathrm{C}$ and $30^{\circ} \mathrm{C}$ revealed that the duration of egg, larva, pupa and adult stages were longest at $15^{\circ} \mathrm{C}$ and shortest at $30^{\circ} \mathrm{C}$. The total developmental period observed at $15^{\circ} \mathrm{C}, 20^{\circ} \mathrm{C}, 25^{\circ} \mathrm{C}$ and $30^{\circ} \mathrm{Cwere}$ : $\hat{\sigma}^{\lambda}-60.5 \pm 1.40$ days; + + $63.2 \pm 1.46$ days, $\widehat{\jmath}-37.4 \pm 1.22$ days; + - $39.8 \pm 1.36$ days, $\widehat{0}-26.4 \pm$ 1.12 days; + - $28.6 \pm 1.10$ days and $\hat{\sigma}-16.4 \pm 0.96$ days; + - $17.9 \pm 0.98$ days, respectively.

\section{Introduction}

Tomato (Solanum lycopersicum) is an intensely nutritious plant with an estimated global production of over 120 million metric tons (F.A.O. 2007). It is the world's largest vegetable crop after potato and sweet potato, and India ranks second in the area as well as in production (Anonymous, 2017). Because of its fleshy nature, tomato fruit is attacked by a number of insect pests and diseases from the time plants first emerge in the seed bed until harvest (Brezeanu et al., 2014).Among the insect pests of tomato, the loss incurred by $L$. trifolii (Burgess) has become most important in recent years (Medeiros et al., 2005).In India the serpentine leaf miner, L. trifolii (Burgess) is one of the recently introduced pest of 
tomato whose infestation is increasing every year at an alarming rate and has acquired a major pest status in recent years (Rai et al., 2013). It is a native of Florida in Southern United States and the Carribean Islands (Spencer, 1973) and was accidentally introduced into India from American subcontinent along with chrysanthemum cuttings (Parrella, 1987). This leaf miner was first described as Oscinistrifolii (Comstock, 1880) and have been known by several common names like serpentine leafminer, American serpentine leafminer, broad bean leafminer, California leafminer, celery leafminer, chrysanthemum leafminer (Malipatil and Ridland, 2008) and in West-Bengal, it is locally known as 'Map poka' by the farmers. Damage to the crop are caused by the adult females and maggots.

The female fly makes feeding and egg laying punctures on the leaves, which results into stippled appearance of foliage (Parrella et al., 1985). However, the major form of damage is the mining of leaves by larvae, which results in destruction of leaf mesophyll. Extensive mining also causes premature leaf drop, which can result in lack of shading and sun scalding of fruit. Wounding of the foliage also allows entry of bacterial and fungal diseases (Capinera, 2017).

The aim of this experiment was to study the biology of L. trifolii on tomato and determine its developmental stages in different temperature regimes as this may help in timely control of the insect pest, develop newer approach of biological control and evaluate effective management strategies.

\section{Materials and Methods}

Experimental studies on the biology of $L$. trifolii were carried out in the Plant Protection Laboratory of Department of Agricultural Entomology, BCKV during 2017-2018. A stock culture was first established in the laboratory. Infested tomato leaves with live mines from the field were collected. These were initially collected in polythene bags from the fields and transferred to glass containers lined with blotting paper and wet cotton to maintain the turgidity of the leaves and covered with fine muslin cloth tied with a rubber band.

After few days the pupae were collected in petridishes (10 $\mathrm{cm}$ diameter) and placed inside a rearing cage of size $1 \mathrm{ft} \times 1 \mathrm{ft}$ for adult emergence. Then freshly emerged male and female adults had been chosen for pairing and placed in glass jar to facilitate incubation studies.

The incubation period, larval period and pupal period were observed and recorded. The adults which emerged from the pupa were introduced individually into a glass jar to study the fecundity and longevity. Fresh tomato leaves were provided with $10 \%$ honey solution for feeding and oviposition.

The leaves were changed regularly after 24 hours interval and the older leaves transferred to another glass jar for emergence of the progenies. The longevities of ten males and females were recorded by observing the duration between emergence to death of adult. The total period for the completion of life cycle was worked out based on the durations of egg, larval, pupal and adult stages respectively. The length and width of ten eggs, larvae, pupae and adults were observed separately under the microscope and recorded.

The developmental periods of the different life stages of L. trifolii were also studied in the laboratory at four controlled temperature of 15 $\pm 1^{\circ} \mathrm{C}, 20 \pm 1^{\circ} \mathrm{C}, 25 \pm 1^{\circ} \mathrm{C}$ and $30 \pm 1^{\circ} \mathrm{C}$. They were conducted on freshly collected tomato leaves introduce in petridishes and glass jars and incubation period up to adult emergence was studied and recorded. 


\section{Results and Discussion}

\section{Biology}

Adults appeared to be very small flies. Mating occurred within 24 hours of emergence from puparia and thereafter the female laid eggs singly in the leaves. Eggs were oval in shape and slightly translucent. There were three larval stages and they predominantly fed on the leaves in which the eggs were laid. Initially, the larva was colourless then became yellowish as it matures. The third and final instar cut an opening at the end of the mine to exit for pupation. The pupa was yellow in color which turned orange brown as it got older. The fly emerged after making a slit on the anterior end of the puparium. Male fly was smaller in size than female. The morphometrics regarding the length and breadth of various developmental stages of $L$. trifoliion tomato i.e. egg, larva (first, second and third instars), pupa, adult male and female are shown in Table 1.

\section{Egg}

The eggs were laid singly on the upper surface of leaf. Freshly laid eggs were oval in shape, white and translucent which turned creamy white at maturity. It measured about $0.21 \pm$ $0.03 \mathrm{~mm}$ in length and $0.11 \pm 0.02$ in breadth. These findings are in close conformity with the observations recorded by Demetry (1971), Beri (1974), Bartlett and Powell (1981), Minkenburg (1988), and Mujica et al., (2016).

\section{Larva}

The first instar larva was apodous, transparent and minute. On an average those measured about $0.54 \pm 0.07 \mathrm{~mm}$ in length and $0.33 \pm$ $0.07 \mathrm{~mm}$ in width. Minkenburg (1988) reported that length of first instar larva was $0.39 \mathrm{~mm}$ and Hemalatha and Uma Maheshwari (2004) reported that a mean length and width of first instar larva was 0.57 $\mathrm{mm}$ and $0.14 \mathrm{~mm}$, respectively on tomato. Gondhalekar (2005) reported that length and width of first instar were $0.44 \mathrm{~mm}$ and 0.17 $\mathrm{mm}$, respectively on gerbera. The second instar larva was observed to be pale yellowish in colour and measured about $1.41 \pm 0.06 \mathrm{~mm}$ in length and $0.5 \pm 0.04 \mathrm{~mm}$ in width. The last and third instar larva showed distinctively yellowish colouration and measured about $2.09 \pm 0.02 \mathrm{~mm}$ in length and $1.19 \pm 0.04 \mathrm{~mm}$ in width. The present findings are in close conformity with that of Hemalatha and Uma Maheshwari (2004) on tomato and Gondhalekar (2005) on gerbera.

\section{Pupa}

The pupa became yellow brown in colour assuming a deeper yellow brown as they matured. The pupae were measured about 1.78 $\pm 0.09 \mathrm{~mm}$ in length and $0.68 \pm 0.06 \mathrm{~mm}$ in breadth. The present findings are in close conformity with that of Okram et al., (2017) who observed pupal length and breadth to be of $1.60 \pm 0.08 \mathrm{~mm}$ and $0.74 \pm 0.03 \mathrm{~mm}$, respectively.

\section{Adult}

The observed colouration and morphology of adult was similar to that of described by Spencer (1973), Barlett and Powell (1981 and Mujica et al., (2016). The head was yellow with reddish eyes and yellow hind margins.

The thorax and abdomen were grayish black with a noticeable yellow patch at the hind end of the mesonotum. The mesonotum was matte, greyish black while the underside and legs were mostly yellow. The wings were transparent. The length of body and wing expanse were found to be in a range of $1.46 \pm$ $0.08 \mathrm{~mm}$ and $1.22 \pm 0.06 \mathrm{~mm}$, respectively in adult males, whereas in case of females the body length and wing expanse were found to be in the range of $1.68 \pm 0.09 \mathrm{~mm}$ and $1.35 \pm$ $0.07 \mathrm{~mm}$, respectively (Table 1). 
Table.1 Morphometric parameters of L. trifolii on tomato

\begin{tabular}{|c|c|c|c|}
\hline \multicolumn{2}{|c|}{ Life stages } & Length (mm) & Breadth $(\mathbf{m m})$ \\
\hline \multicolumn{2}{|c|}{ Egg } & $0.21 \pm 0.03$ & $0.11 \pm 0.02$ \\
\hline \multicolumn{2}{|c|}{ 1st Instar } & $0.54 \pm 0.07$ & $0.33 \pm 0.07$ \\
\hline \multicolumn{2}{|c|}{ 2nd Instar } & $1.41 \pm 0.06$ & $0.52 \pm 0.04$ \\
\hline \multicolumn{2}{|c|}{ 3rd Instar } & $2.09 \pm 0.02$ & $1.19 \pm 0.04$ \\
\hline \multicolumn{2}{|c|}{ Pupa } & $1.78 \pm 0.09$ & $0.68 \pm 0.06$ \\
\hline \multirow[t]{2}{*}{ Adult } & Male & $1.46 \pm 0.08$ (body length) & $1.22 \pm 0.06$ (wing length) \\
\hline & Female & $1.68 \pm 0.09$ (body length) & $1.35 \pm 0.07$ (wing length) \\
\hline
\end{tabular}

Table.2 Developmental period (in days) of $L$. trifolii at $15^{\circ} \mathrm{C}, 20^{\circ} \mathrm{C}, 25^{\circ} \mathrm{C}$ and $30^{\circ} \mathrm{C}$ on tomato

\begin{tabular}{|c|c|c|c|c|c|}
\hline \multicolumn{2}{|c|}{ Life stages } & $\begin{array}{c}\mathbf{1 5}^{\circ} \mathbf{C} \\
(\mathbf{m e a n} \pm \mathbf{S D}) \\
(\mathbf{D a y s})\end{array}$ & $\begin{array}{c}\mathbf{2 0}^{\circ} \mathbf{C} \\
(\mathbf{m e a n} \pm \mathbf{S D}) \\
(\mathbf{D a y s})\end{array}$ & $\begin{array}{c}\mathbf{2 5}^{\circ} \mathbf{C} \\
(\mathbf{m e a n} \pm \mathbf{S D}) \\
(\mathbf{D a y s})\end{array}$ & $\begin{array}{c}\mathbf{3 0}^{\circ} \mathbf{C} \\
(\mathbf{m e a n} \pm \mathbf{S D}) \\
(\mathbf{D a y s})\end{array}$ \\
\hline \multirow{2}{*}{ Egg } & $8.6 \pm 0.97$ & $5.4 \pm 0.84$ & $3.8 \pm 0.92$ & $1.9 \pm 0.74$ \\
\hline \multirow{2}{*}{ Larva } & $13.7 \pm 1.57$ & $6.4 \pm 1.3$ & $4.9 \pm 0.99$ & $3.5 \pm 0.85$ \\
\hline \multirow{2}{*}{ Adult } & Pupal & $22.4 \pm 1.71$ & $14.7 \pm 1.49$ & $10.2 \pm 1.32$ & $6.9 \pm 1.37$ \\
\cline { 2 - 7 } & Male & $15.1 \pm 1.37$ & $10.90 \pm 1.20$ & $7.5 \pm 1.27$ & $3.9 \pm 0.88$ \\
\hline \multirow{2}{*}{ Total } & Female & $18.5 \pm 1.58$ & $13.3 \pm 1.77$ & $9.7 \pm 1.16$ & $5.4 \pm 0.97$ \\
\cline { 2 - 7 } & Male & $60.5 \pm 1.40$ & $37.4 \pm 1.22$ & $26.4 \pm 1.12$ & $16.4 \pm 0.96$ \\
\hline
\end{tabular}

These findings are in agreement with the findings by Okram et al., (2017) who observed that male flies were smaller in size than the female flies. Parrella (1987) also reported a similar finding that adult females were usually larger than males and emerged from larger puparia.

Effect of different temperature regimes $\left(15^{\circ} \mathrm{C}, 20{ }^{\circ} \mathrm{C}, 25{ }^{\circ} \mathrm{C}\right.$ and $\left.30{ }^{\circ} \mathrm{C}\right)$ on the developmental period (in days) of $L$. trifolii on tomato

The results pertaining the developmental period of various life stages of $L$. trifolii on tomato in different levels of temperature i.e. $15^{\circ} \mathrm{C}, 20^{\circ} \mathrm{C}, 25^{\circ} \mathrm{C}$ and $30^{\circ} \mathrm{C}$ in Table 2 revealed that temperature had a significant effect on the developmental time of egg, larva, pupa and adult of L. trifolii. The eggs took significantly longer time to hatch at $15^{\circ} \mathrm{C}(8.6$ \pm 0.97 days) and significantly shorter time at $30^{\circ} \mathrm{C}(1.9 \pm 0.74$ days $)$. At temperatures $20^{\circ} \mathrm{C}$ and $25^{\circ} \mathrm{C}$ the egg period observed were $5.4 \pm$ 0.84 days and $3.8 \pm 0.92$ days respectively. Similar findings are reported by Leibee (1984) who found that the incubation period of eggs of $L$. trifolii were $1.99 \pm 0.03,2.38 \pm 0.05$, $2.33 \pm 0.04,4.4 \pm 0.04$ and $9.97 \pm 0.47$ days at $35^{\circ} \mathrm{C}, \quad 30^{\circ} \mathrm{C}, \quad 25^{\circ} \mathrm{C}, \quad 20^{\circ} \mathrm{C}$ and $15^{\circ} \mathrm{C}$, respectively. Lanzoni et al., (2002) also noted that the development time for egg ranged between, $6.3 \pm 0.7$ days, $3.6 \pm 0.2$ days, $2.1 \pm$ 0.1 days and $1.6 \pm 0.1$ days at $15^{\circ} \mathrm{C}, 20^{\circ} \mathrm{C}$, $25^{\circ} \mathrm{C}$, and $30^{\circ} \mathrm{C}$, respectively. Further, Parella (1987) reported that the period of egg development varies with temperature and ranges from 2-8 days. The larval period observed at $15^{\circ} \mathrm{C}$ was $13.7 \pm 1.57$ days, at $20^{\circ} \mathrm{C}$ it was $6.4 \pm 1.3$, at $25^{\circ} \mathrm{C}$ it was $4.9 \pm 0.99$ 
days and at $30^{\circ} \mathrm{C}$ it was $3.5 \pm 0.85$ days. These are findings are more or less in close conformity with that of Lanzoni et al., (2002) who reported that the larval period ranged from $14.3 \pm 1.1$ days, $6.7 \pm 0.5$ days, $4.6 \pm 0.5$ days and $3.6 \pm 0.4$ days at $15^{\circ} \mathrm{C}, 20^{\circ} \mathrm{C}, 25^{\circ} \mathrm{C}$, and $30^{\circ} \mathrm{C}$, respectively. A similar trend was reported by Van Elferen and Yarhom (1989) where the larval period $( \pm \mathrm{SE})$ at temperatures of 20,25 and $30^{\circ} \mathrm{C}$ were $9.9 \pm 0.2,4.4 \pm 0.1$ and $3.7 \pm 0.1$ on gypsophila and $5.5 \pm 0.1,3.7 \pm 0.1$ and $2.4 \pm 0.1$ days, on bean, respectively. Thepupal and the adult developmental periods were also found to vary with temperature. Lowest pupal development time $(6.9 \pm 1.37)$ was recorded at $30^{\circ} \mathrm{C}$ and highest development time $(22.4 \pm 1.71)$ was recorded at $15^{\circ} \mathrm{C}$. The pupal period at $20^{\circ} \mathrm{C}$ and $25^{\circ} \mathrm{C}$ were found to be $14.7 \pm 1.49$ days and $10.2 \pm$ 1.32days, respectively. Lanzoni et al., (2002) reported the pupal period to be $33.2 \pm 2.3$ days, $13.3 \pm 0.6$ days, $9.2 \pm 0.4$ days and $6.9 \pm$ 0.3 days at $15,20,25$, and $30^{\circ} \mathrm{C}$, respectively. Similarly, Van Elferen and Yarhom, (1989) also observed that the pupal period at 17, 20, 25 and $30^{\circ} \mathrm{C}$ lasted $19.9 \pm 0.2,14.7 \pm 0.1$, $10.4 \pm 0.1$ and $7.8 \pm 0.1$ days, respectively. The adult male development period was noted to be $15.1 \pm 1.37$ days at $15^{\circ} \mathrm{C}, 10.90 \pm 1.20$ days at $20^{\circ} \mathrm{C}, 7.5 \pm 1.27$ days at $25^{\circ} \mathrm{C}$ and $3.9 \pm$ 0.88 days at $30^{\circ} \mathrm{C}$, while for adult female it was $18.5 \pm 1.58$ days, $13.3 \pm 1.77$ days, $9.7 \pm$ 1.16 days and $5.4 \pm 0.97$ days at $15^{\circ} \mathrm{C}, 20^{\circ} \mathrm{C}$, $25^{\circ} \mathrm{C}$ and $30^{\circ} \mathrm{C}$, respectively. The total developmental period was longest at $15^{\circ} \mathrm{C}(\widehat{\diamond}-$ $60.5 \pm 1.40$ days; $9-63.2 \pm 1.46$ days $)$ with the minimum period ( $\hat{0}-16.4 \pm 0.96$ days; $\circ$ $17.9 \pm 0.98$ days) observed at $30^{\circ} \mathrm{C}$. At temperatures $20^{\circ} \mathrm{C}$ and $25^{\circ} \mathrm{C}$, the total period observed were; $\hat{\jmath}-37.4 \pm 1.22$ days; - $-39.8 \pm$ 1.36 days and $\hat{\jmath}-26.4 \pm 1.12$ days; + - $28.6 \pm$ 1.10 days, respectively. These findings are in agreement with results of studies carried out by Liebee (1984), Parella (1987) and Minkenberg (1988) who observed similar trends on Liriomyza genus (L. huidobrensis, $L$. sativa and L. trifolii). It is also in agreement with Head et al., (2002) who carried out studies on the developmental rates of leafminers in lettuce at different temperatures $\left(11-28^{\circ} \mathrm{C}\right)$. His study revealed a linear increase in developmental rates with temperature. As with all insects, the rate of immature development of Liriomyza spp. is dependent on temperature. Similar observations were made by Parella (1987) who found that longevity decreased with an increase in temperature. Thus, it can be concluded from the findings above that temperature played a significant role in the development period of leaf miner and showed an inverse relationship with temperature.

\section{References}

Anonymous, 2016-17. National Horticulture Board (NHB). 2016-17. Indian Horticulture Database 2017, Ministry of Agriculture, Government of India.

Bartlett, P. W. and Powell, D. F. 1981. Introduction of American serpentine leaf miner, Liriomyza trifolii, into England and Wales and its eradication from commercial nurseries, 1977-81. Plant Pathology, 30: 185-193.

Beri, S. K. 1974. Biology of the leaf miner Liriomyza brassicae (Riley) (Diptera: Agromyzidae). Journal of Natural History, 8(2): 143-151.

Brezeanu, P. M., Brezeanu, C., Ambarus, S., Calin, M., Cristea, T. O. 2014. A review of the most important pest insects and its influence on tomato culture. Scientific Study \& Research - Animal Biology, 23(2): 68-73.

Capinera, J. L. 2017. American Serpentine Leafminer, Liriomyza trifolii (Burgess) (Insecta: Diptera: Agromyzidae). EENY254. University of Florida. http://edis.ifas.ufl.edu.

Comstock, 1880. Report of the Commissioner of Agriculture for the Year 1879. Washington, USA: Report of the Entomologist Government Printing Office, 200-201. 
Demetry, N. Z. 1971. Biological studies on a leaf mining Diptera, Liriomyza trifolii (Burgess) attacking beans in Egypt. Bulletin de la Societe Entomologiqued' Egypte, 55: 55-69.

FAO (Food and Agricultural Organization), 2007. FAOStat, core production 2005.http://faostat.fao.org/site/340/default. aspx.

Gondhalekar, A. D. 2005. Studies on serpentine leafminer ( $L$. trifolii) infesting gerbera (Gerbera jamesonii Hooker) under polyhouse condition. M. Sc. (Agri) thesis submitted to M.P.K.V., Rahuri.

Hemalatha, B. and Uma Maheshwari, T. 2004. Biology and management of serpentine leafminer, Liromyzatrifolii Burgess on tomato in southern zone of Andhra Pradesh. Indian Journal of Entomology, 66(2): 107-110.

Lanzoni, A., Bazzocchi, G. G., Burgio, G. and Fiacconi, M. R. 2002. Comparative life history of Liriomyza trifolii and Liriomyza huidobrensis (Diptera: Agromyzidae) on beans: effect of temperature on development. Environmental Entomology, 31(5): 797-803.

Leibee, G. L. 1984. Influence of temperature on development and fecundity of Liriomyza trifolii (Burgess) (Diptera: Agromyzidae) on celery. Environmental Entomology, 13: 497-501.

Malipatil, M., and Ridland, P. 2008. Liriomyza trifolii, Polyphagous agromyzid leafminers. Department of Agriculture, Fisheries and Forestry, Victoria.

Medeiros, M.A., Villas Boas, G.L., Carrijo, O.A., Makishima, N. and Vilela, N.J. 2005. Embrapa Vegetables Circular Technician, 36: 10.

Minkenberg, O. P. J. M. 1988. Life history of the agromyzid fly Liriomyza trifolii on tomato at different temperatures. Entomologica Experimentalis et Appliciata, 48: 73-84.

Mujica, N., Khadioli, N., Le Ru, B., Ong'amo, G. and Carhuapoma, P. (2016). American serpentine leafminer, Liriomyza trifolii (Burgess 1880). In: Kroschel, J.; Mujica, N.; Carhuapoma, P.; Sporleder, M. (eds.). Pest distribution and risk atlas for Africa. Potential global and regional distribution and abundance of agricultural and horticultural pests and associated biocontrol agents under current and future climates. Lima (Peru). International Potato Center (CIP). ISBN 978-92-9060-476-1. DOI 10.4160/9789290604761-11. pp. 139153.

Okram, S., Das, U. and Saikia, K. 2017. Biology and management of tomato leaf miner (Liriomyza trifolii) in Meghalaya. The Bioscan, 12(1): 43-45.

Parella, M. P. 1987. Biology of Liriomyza. Annual Reviews of Entomology, 32:201-224.

Parrella, M. P., Jones, V. P. Youngman, R. R. and LeBeck, L. M. 1985. Effect of leaf mining and leaf stippling of Liriomyza spp. on photosynthetic rates of chrysanthemum. Annals of the Entomological Society of America, 78: 90-93

Rai, D., Singh, A. K., Sushil, S. N., Rai, M. K., Gupta, J. P., and Tyagi, M. P. 2013. Efficacy of Insecticides against American Serpentine Leaf Miner, Liriomyza trifolii (Burgess) on Tomato Crop in N-W region of Uttar Pradesh, India International Journal of Horticulture 3(5): 19-21.

Spencer, K. A. 1973. Agromyzidae (Diptera) of economic importance. Series Entomologica, 9: 1-418.

Van Elferen, J. H. W. M. and Yathom, S. 1989. The bionomics of Liriomyza trifolii on Gypsophila and Bean Leaves. Phytoparasitica, 17: 241-250.

\section{How to cite this article:}

Kasar, N. and Jha, S. 2021. Biology of Leaf Miner, Liriomyza trifolii (Burgess) on Tomato and the Effect of Different Temperature Regimes on its Developmental Period. Int.J.Curr.Microbiol.App.Sci. 10(02): 2370-2375. doi: https://doi.org/10.20546/ijcmas.2021.1002.281 
Int.J.Curr.Microbiol.App.Sci (2021) 10(02): 2370-2375 